\title{
Zoonotic Cryptosporidium species and subtypes in lambs and goat kids in Algeria
}

\author{
Djamel Baroudi ${ }^{1,2}$, Ahcene Hakem $^{3}$, Haileeyesus Adamu ${ }^{4}$, Said Amer ${ }^{5}$, Djamel Khelef ${ }^{1}$, Karim Adjou ${ }^{6}$, \\ Hichem Dahmani ${ }^{7}$, Xiaohua Chen ${ }^{8}$, Dawn Roellig ${ }^{2}$, Yaoyu Feng ${ }^{9}$ and Lihua Xiao ${ }^{*^{*}}$
}

\begin{abstract}
Background: Little is known on the occurrence and identity of Cryptosporidium species in sheep and goats in Algeria. This study aimed at investigating the occurrence of Cryptosporidium species in lambs and goat kids younger than 4 weeks.
\end{abstract}

Methods: A total of 154 fecal samples ( 62 from lambs and 92 from kid goats) were collected from 13 sheep flocks in Médea, Algeria and 18 goat flocks across Algiers and Boumerdes. They were screened for Cryptosporidium spp. by nested-PCR analysis of a fragment of the small subunit (SSU) rRNA gene, followed by restriction fragment length polymorphism and sequence analyses to determine the Cryptosporidium species present. Cryptosporidium parvum and C. ubiquitum were further subtyped by sequence analysis of the $60 \mathrm{kDa}$ glycoprotein gene.

Results: Cryptosporidium spp. were detected in 17 fecal samples (11.0\%): 9 from lambs (14.5\%) and 8 from goat kids (8.7\%). The species identified included C. parvum in 3 lambs, C. xiaoi in 6 lambs and 6 goat kids, and C. ubiquitum in 2 goat kids. Cryptosporidium infections were detected mostly in animals during the first two weeks of life (7/8 for goat kids and $7 / 9$ for lambs) and in association with diarrhea occurrence $(7 / 17$ or $41.2 \%$ goat kids and $7 / 10$ or $70.0 \%$ lambs with diarrhea were positive for Cryptosporidium spp.). Subtyping of C. parvum and C. ubiquitum isolates identified the zoonotic IlaA13G2R1 and Xlla subtype families, respectively. Minor differences in the SSU rRNA gene sequences were observed between C. xiaoi from sheep and goats.

Conclusions: Results of this study indicate that three Cryptosporidium species occur in lambs and goat kids in Algeria, including zoonotic C. parvum and C. ubiquitum. They are associated with the occurrence of neonatal diarrhea.

Keywords: Cryptosporidium parvum, Cryptosporidium ubiquitum, Cryptosporidium xiaoi, Goat, Sheep, Algeria

\section{Background}

Cryptosporidium spp. are common enteric protozoa of humans and a wide range of animals [1]. They are involved in numerous outbreaks of diarrheal illness in humans and pre-weaned calves [2,3]. However, studies of Cryptosporidium spp. in small ruminants are much smaller in numbers compared to those in cattle, especially from developing countries [4-6]. Data accumulated thus far indicate that cryptosporidiosis in small ruminants can lead to severe diarrhea, anorexia and weight loss in goat kids and lambs [5, 7-9]. Considerably

\footnotetext{
*Correspondence: Ixiao1961@gmail.com

${ }^{9}$ Key Laboratory of Zoonosis of Ministry of Agriculture, College of Veterinary Medicine, South China Agricultural University, Guangzhou 510642, China Full list of author information is available at the end of the article
}

high infection rates have been reported in these animals in some areas [10-14].

Currently, over 30 Cryptosporidium species have been recognized based on morphological, biological and molecular characteristics (reviewed in [1]). Among them, $C$. parvum, C. ubiquitum and C.xiaoi are common species in small ruminants, although a small number of animals were reportedly infected with other Cryptosporidium species such as $C$. andersoni and $C$. hominis $[4,5,14-18]$. Geographical variations in the distribution of these Cryptosporidium spp. in small ruminants, however, have been described among the small number of studies conducted [19]. The common occurrence of zoonotic C. parvum and C. ubiquitum in goats and sheep has raised public health concerns over cryptosporidiosis. While $C$. 
parvum is well known for causing diarrhea in small ruminants, the pathogenicity of $C$. ubiquitum and C. xiaoi remains unclear [2].

Algeria is adopting intensive farming of small ruminants to cope with the high demand for meat and milk. A recent estimate from the Ministère De L'Agriculture et du Développement Rural indicates that the country has approximately 2,800,000 sheep and 490,000 goats (http:// www.minagri.dz/contacts.html). Although Cryptosporidium spp. from cattle, horses, camels and chickens have been recently characterized using molecular biological tools [20-23], little information is available on the identity of Cryptosporidium spp. in goats and sheep. In the present study we therefore generated some preliminary data on the occurrence of Cryptosporidium species in goat kids and lambs in Algeria.

\section{Methods}

\section{Collection of samples}

This study was conducted between January 2012 and January 2014 on 13 sheep flocks in Ksar el Boukhari of Médea Province (No. 1), and 18 goat flocks from seven localities in the provinces of Algiers (Nos 2, 3, 4, 5) and Boumerdes (Nos 6, 7, 8) (Fig. 1). A total of 92 and 62 fecal samples were collected directly from the rectum of goat kids and lambs, respectively. Only animals aged 4 weeks or younger were sampled. Fecal consistency and demographic data on the animals were recorded at the site of sample collection. The samples were transported to the laboratory in ice boxes and preserved in $2.5 \%$ potassium dichromate at $4{ }^{\circ} \mathrm{C}$ until molecular analysis.

\section{DNA extraction and PCR analysis}

Potassium dichromate was washed off fecal samples with distilled water by centrifugation. Genomic DNA was extracted from $0.2 \mathrm{ml}$ of fecal slurry without further pathogen concentration using the FastDNA SPIN Kit for Soil (BIO 101, MP Biomedicals, Carlsbad, CA, USA). DNA preparations were screened for Cryptosporidium spp. by using a small subunit ( $S S U$ ) rRNA-based nested PCR, with DNA of $C$. baileyi as the positive control and reagent-grade water as the negative control. The detection limit of the approach was $\sim 10$ oocysts per gram of feces. Cryptosporidium species in positive PCR products were determined by restriction fragment length polymorphism (RFLP) analysis using restriction enzymes SspI and MboII as described [24] and by DNA sequencing. Cryptosporidium parvum and C. ubiquitum were subtyped by nested-PCR-sequence analysis of the gp60 gene as previously described $[25,26]$.

\section{DNA sequence analysis}

To confirm the identification of $C$. ubiquitum and $C$. $x i a o i$, the secondary PCR products of the SSU rRNA gene from the two Cryptosporidium species were sequenced in both directions on an ABI 3130 Genetic Analyzer (Applied Biosystems, Foster City, CA, USA). The SSU rRNA gene products of $C$. parvum were not sequenced because it has a well-known $S s p$ I and MboII RFLP pattern. In addition, all PCR products of the gp60 gene were sequenced to identify C. parvum and C. ubiquitum subtypes. The generated sequences were assembled using the

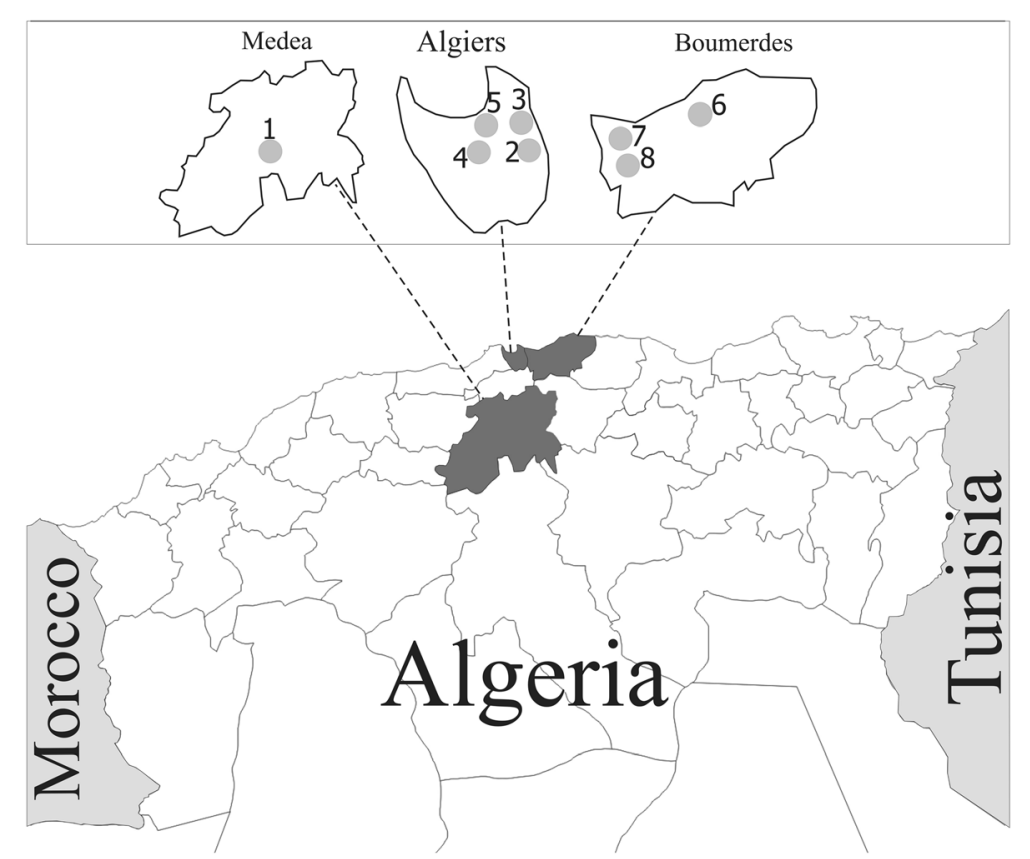

Fig. 1 Map of Algeria indicating the locations of sheep and goats in Medea, Algiers and Boumerdes provinces 
ChromasPro v.1.5 software (http://www.technelysium. com.au/ChromasPro.html) and aligned with each other and reference sequences downloaded from GenBank using ClustalX (http://www.clustal.org/). Representative sequences generated in the study were submitted to GenBank under accession numbers LC414387-LC414393 for the SSU rRNA gene and LC414394 and JX412917 for the gp60 gene of C. parvum and C. ubiquitum, respectively.

\section{Statistical analysis}

Cryptosporidium infection rates between diarrheic and non-diarrheic animals were compared statistically using Fisher's exact test implemented in the Statistical Package for the Social Sciences (SPSS version 22.0). Differences were considered significant at $P \leq 0.05$.

\section{Results}

\section{Occurrence of Cryptosporidium spp. in goat kids and} lambs

Cryptosporidium spp. were detected in 8/92 (8.7\%) fecal samples from goat kids and in 9/62 (14.5\%) fecal samples from lambs, with an overall infection rate of $11.0 \%$. They were present on 3/18 goat farms and 4/9 sheep farms (Table 1). Most Cryptosporidium-positive samples were from animals up to 3 weeks of age with diarrhea for both goats and sheep (Table 2).

\section{Cryptosporidium species and subtypes}

The RFLP analysis of the SSU rDNA PCR products identified two Cryptosporidium species in goat kids, including C. xiaoi in 6 of 8 Cryptosporidium-positive samples and C. ubiquitum in 2 of 8 Cryptosporidium-positive samples (Fig. 2). Cryptosporidium xiaoi was detected in Rouiba (Algiers) and Zemouri (Boumerdes), while $C$. ubiquitum was seen in Khemis-elkhechna (Boumerdes). In lambs, $C$. parvum was present in 3 of 9 Cryptosporidium-positive and C. xiaoi was identified in the 6 of 9 Cryptosporidium-positive samples from Ksar-elBoukhri (Médea). DNA sequencing of SSU rDNA PCR products confirmed the detection of C. ubiquitum and C. xiaoi in these samples.

Data from 12 samples of C.xiaoi (six each from sheep and goats) generated two sequence types. The first type was represented by six sequences from sheep and was identical to one C. xiaoi sequence (DQ871346) first obtained from a yak in China [24]. The second sequence type was represented by six sequences from goats and was identical to one C.xiaoi sequence (EF362478) first obtained from a sheep in the USA [27]. There were two nucleotide differences in the partial SSU rRNA gene between the two sequence types (substitution of TT in the first type by $\mathrm{CA}$ in the second sequence type at position 420 and 421 of the reference sequence EF362478). The two sequences of the SSU rRNA gene fragment of $C$. ubiquitum were identical to each other and to AF442484 initially detected in lemurs in the USA [28].

Sequence analysis of the gp60 gene indicated that the three C. parvum-positive samples from lambs had the IIaA13G2R1 subtype, whereas the two C. ubiquitum-positive samples from goat kids had the XIIa subtype.

\section{Occurrence of Cryptosporidium spp. by age}

In goat kids, Cryptosporidium was detected in $2 / 22$ (9.1\%), $5 / 25$ (20.0\%), $1 / 27(3.9 \%)$ and $0 / 18(0 \%)$ of the animals sampled in the first, second, third and fourth week of age, respectively. In contrast, Cryptosporidium was detected in $3 / 15$ (20.0\%), 4/18 (22.2\%), 1/13 (7.7\%) and $1 / 16(6.3 \%)$ lambs sampled in the first, second, third and fourth week of age, respectively. In goat kids, $C$. xiaoi was mostly seen during the first three weeks of age, with two cases $(2 / 22 ; 9.1 \%)$ in the first week, three cases $(3 / 25 ; 12.0 \%)$ in the second week, and one case in the third week $(1 / 27 ; 3.7 \%)$. The two C. ubiquitum cases identified in goat kids were seen in the second week of age $(2 / 25 ; 8.0 \%)$ (Table 2$)$. In lambs, one C. parvum infection was detected in the first week of age $(1 / 15 ; 6.7 \%)$ and the other two infections in the second week $(2 / 18$; $11.1 \%)$, while $C$. xiaoi was detected in four animals

Table 1 Cryptosporidium species in goat kids and lambs in Algiers, Boumerdes and Médea provinces, Algeria

\begin{tabular}{|c|c|c|c|c|c|c|}
\hline Location & $\begin{array}{l}\text { No. of } \\
\text { farms }\end{array}$ & Host & $\begin{array}{l}\text { No. of } \\
\text { samples }\end{array}$ & $\begin{array}{l}\text { No. positive for Cryptosporidium } \\
\text { (no. of positive farms) }\end{array}$ & $\begin{array}{l}\text { Cryptosporidium spp. } \\
\text { (no. of samples) }\end{array}$ & $\begin{array}{l}\text { Subtype } \\
\text { (no. of samples) }\end{array}$ \\
\hline Ksar-el Boukhari (Médea) & 13 & Sheep & 62 & $9(4)$ & C. xiaoi (6), C. parvum (3) & IlaA13G2R1(3) \\
\hline Rouiba (Algiers) & 3 & Goats & 16 & $3(1)$ & C. xiaoi (3) & - \\
\hline Bordj-El-Kiffan (Algiers) & 2 & Goats & 11 & 0 & 0 & - \\
\hline Heraoua (Algiers) & 2 & Goats & 9 & 0 & 0 & - \\
\hline Khemis-elkhechna (Boumerdes) & 2 & Goats & 11 & $2(1)$ & C. ubiquitum (2) & Xlla (2) \\
\hline Hamadi (Boumerdes) & 3 & Goats & 17 & 0 & 0 & - \\
\hline Zemouri (Boumerdes) & 4 & Goats & 15 & $3(1)$ & C. xiaoi (3) & - \\
\hline Oued-smar (Algiers) & 2 & Goats & 13 & 0 & 0 & - \\
\hline Total & 31 & & 154 & $17(7)$ & 3 species & 2 subtypes \\
\hline
\end{tabular}


Table 2 Occurrence of Cryptosporidium spp. in goat kids by age and diarrhea status

\begin{tabular}{|c|c|c|c|}
\hline Distribution & $\begin{array}{l}\text { No. of } \\
\text { samples }\end{array}$ & $\begin{array}{l}\text { No. positive for } \\
\text { Cryptosporidium (\%) }\end{array}$ & $\begin{array}{l}\text { Cryptosporidium spp } \\
\text { (no. of samples) }\end{array}$ \\
\hline \multicolumn{4}{|l|}{ By age (days) } \\
\hline $1-7$ & 22 & $2(9.1)$ & C. xiaoi (2) \\
\hline $8-14$ & 25 & $5(20.0)$ & $\begin{array}{l}\text { C. xiaoi (3), C. } \\
\text { ubiquitum (2) }\end{array}$ \\
\hline $15-21$ & 27 & $1(3.7)$ & C. xiaoi (1) \\
\hline $22-28$ & 18 & 0 & \\
\hline \multicolumn{4}{|c|}{ By age (days) and diarrhea status } \\
\hline \multicolumn{4}{|c|}{$1-7$} \\
\hline Diarrheic & 8 & $2(25.0)$ & C. xiaoi (2) \\
\hline Non-diarrheic & 14 & $0(0)$ & \\
\hline \multicolumn{4}{|l|}{$8-14$} \\
\hline Diarrheic & 9 & $5(55.6)$ & $\begin{array}{l}\text { C. xiaoi (3), C. } \\
\text { ubiquitum (2) }\end{array}$ \\
\hline Non-diarrheic & 16 & $0(0)$ & \\
\hline \multicolumn{4}{|l|}{$15-21$} \\
\hline Diarrheic & 4 & $1(25.0)$ & C. xiaoi (1) \\
\hline Non-diarrheic & 23 & $0(0)$ & \\
\hline \multicolumn{4}{|l|}{$22-28$} \\
\hline Diarrheic & 2 & $0(0)$ & \\
\hline Non-diarrheic & 16 & $0(0)$ & \\
\hline Total & 92 & $8(8.7)$ & $\begin{array}{l}\text { C. xiaoi (6), C. } \\
\text { ubiquitum (2) }\end{array}$ \\
\hline
\end{tabular}

during the first two weeks $(2 / 15 ; 13.3 \%$ and $2 / 18 ; 11.1$, respectively) and two animals during the third and fourth weeks $(1 / 13 ; 7.7 \%$ and $1 / 16 ; 6.3 \%$, respectively) (Table 2).

\section{Occurrence of Cryptosporidium spp. by diarrhea status}

Altogether, 23 of the 92 fecal samples (25.0\%) were collected from goat kids with diarrhea, including 8/92 $(8.7 \%)$ in the first week, $9 / 92(9.8 \%)$ in the second week, 4/92 (4.3\%) in the third week, and 2/92 (2.2 $\%$ ) in the fourth week of age (Tables 2, 3). All Cryptosporidium infections in goat kids were detected in animals with diarrhea. At the first week of age, Cryptosporidium infection was detected in 2/8 (25.0 \%) diarrheic kids, with C. xiaoi as the only Cryptosporidium species involved. At the second week of age, Cryptosporidium was observed in 5/9 (55.6 \%) diarrheic animals, including C. xiaoi (3/5) and C. ubiquitum (2/5). At the third week of age, Cryptosporidium was present in $1 / 4$ (25.0\%) diarrheic ones, with the species being diagnosed as C. xiaoi. The occurrence of cryptosporidiosis in diarrheic goat kids (34.8\%) was statistically higher compared to that in non-diarrheic $(0.0 \%)$ ones $(P=0.0000001)$.
Among the 62 fecal samples collected from lambs, 13 $(21.0 \%)$ were from diarrheic animals, including 4 in the first week, 6 in the second week, and 3 in the third week of age. Cryptosporidium was detected in 3/4 (75.0\%), 4/6 $(66.7 \%)$ and $1 / 3(33.3 \%)$ of the diarrheic lambs in the first, second and third weeks, respectively (Tables 2,3 ). Among them, C. parvum was detected in $1 / 3$ and $2 / 4$ of the Cryptosporidium-positive samples in the first and second week, respectively. C. xiaoi was found in diarrheic animals up to 3 weeks of age and in non-diarrheic ones after that (Table 2). Thus, the overall infection rate in lambs was $14.5 \%$, with the infection rate in diarrheic ones reaching $61.5 \%(8 / 13)$, compared with $2.0 \%(1 / 49)$ in non-diarrheic ones $(P=0.0000003)$.

\section{Discussion}

In the present study, the occurrence and genotype and subtype identity of Cryptosporidium spp. in goat kids and lambs in Algeria were examined. The overall infection rate of Cryptosporidium spp. was $11.0 \%$ (8.7\% in goat kids and $14.5 \%$ in lambs). Previous studies reported Cryptosporidium infection rates of $5.1-82.0 \%$ in sheep and $7.1-93.0 \%$ in goats in industrialized nations $[4,10$, 14, 16, 29-35]. Few comparable data are available from 


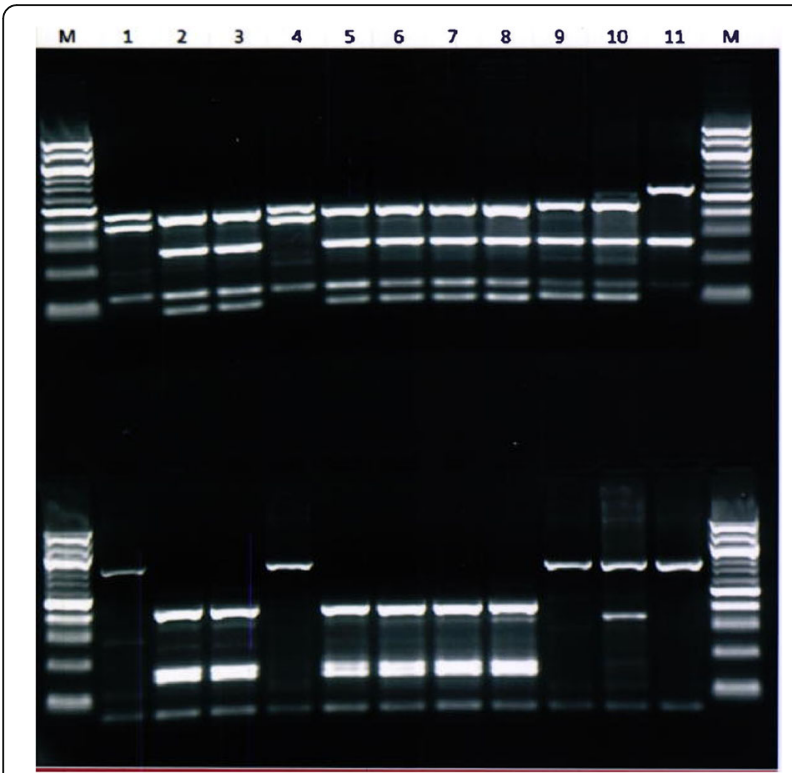

Fig. 2 Differentiation of Cryptosporidium ubiquitum (Lanes 1, 4), C. xiaoi (Lanes 2, 3, 5-8), and C. parvum (Lanes 9, 10) from lambs and goat kids by RFLP analysis of the SSU rDNA PCR products using restriction enzymes Sspl (upper panel) and Mboll (lower panel). Lane 11: positive control (C. baileyi); Lane M: 100 bp molecular markers. The extra Mboll band in Lane 10 is due to the presence of a non-specific band in the PCR product developing countries, but infection rates of 2.5-67.5 and $2.9-72.5 \%$ have been reported in sheep and goats, respectively, in Zambia, Egypt, China, Bangladesh, Iran, Argentina and México [11-13, 17, 36-41]. Variations in infection rates among studies could be attributed to the differences in animal age, diagnostic methods, sample sizes, animal management and climates.

In this study, three Cryptosporidium species were identified in small ruminants, including C. parvum, $C$. xiaoi and C. ubiquitum. In both goats and sheep C. xiaoi appeared to be the dominant species (6/8 in goats and 6/9 in sheep), with C. ubiquitum being detected only in two of the eight Cryptosporidium-positive goats and $C$. parvum in three of the nine Cryptosporidium-positive sheep. In concordance with this, C.xiaoi was detected as a dominant species in small ruminants in other African countries including Egypt [37] and Tanzania [42] as well as Asian countries such as Bangladesh [40] and China [11, 17, 41, 43]. Similarly, C. xiaoi was the major Cryptosporidium species in small ruminants in some developed countries such as France [34], Greece [18], Norway [44], Poland [14] and Australia [35, 45]. In the presence study, two types of SSU rDNA sequences were obtained from C. xiaoi, with sheep and goats having different types. Both sequence types, however, have been observed in both sheep and goats in previous studies based on BLAST analysis of GenBank sequences. As sheep and goat samples from the present study were collected from

Table 3 Occurrence of Cryptosporidium spp. in lambs by age and diarrhea status

\begin{tabular}{|c|c|c|c|}
\hline Distribution & $\begin{array}{l}\text { No. of } \\
\text { samples }\end{array}$ & $\begin{array}{l}\text { No. positive for } \\
\text { Cryptosporidium (\%) }\end{array}$ & $\begin{array}{l}\text { Cryptosporidium spp. } \\
\text { (no. of samples) }\end{array}$ \\
\hline \multicolumn{4}{|l|}{ By age (days) } \\
\hline $1-7$ & 15 & $3(20.0)$ & C. xiaoi (2), C. parvum (1) \\
\hline $8-14$ & 18 & $4(22.2)$ & C. xiaoi (2), C. parvum (2) \\
\hline $15-21$ & 13 & $1(7.7)$ & C. xiaoi (1) \\
\hline $22-28$ & 16 & $1(6.3)$ & C. xiaoi (1) \\
\hline \multicolumn{4}{|c|}{ By age (days) and diarrhea status } \\
\hline \multicolumn{4}{|l|}{$1-7$} \\
\hline Diarrheic & 4 & $3(75.0)$ & C. xiaoi (2), C. parvum (1) \\
\hline Non-diarrheic & 11 & $0(0)$ & \\
\hline \multicolumn{4}{|l|}{$8-14$} \\
\hline Diarrheic & 6 & $4(66.7)$ & C. xiaoi (2), C. parvum (2) \\
\hline Non-diarrheic & 12 & $0(0)$ & \\
\hline \multicolumn{4}{|l|}{$15-21$} \\
\hline Diarrheic & 3 & $1(33.3)$ & C. xiaoi (1) \\
\hline Non-diarrheic & 10 & $0(0)$ & \\
\hline \multicolumn{4}{|l|}{$22-28$} \\
\hline Diarrheic & 0 & $0(0)$ & \\
\hline Non-diarrheic & 16 & $1(6.25)$ & C. xiaoi (1) \\
\hline Total & 62 & $9(14.5)$ & C. xiaoi (6), C. parvum (3) \\
\hline
\end{tabular}


different areas, it is unclear whether the two types represent different types of $C$. xiaoi circulating in different areas.

Cryptosporidium parvum was seen in three sheep among the small number of animals examined. These findings are in agreement with previous common findings of the pathogen in sheep in European countries and Australia [4, 10, 18, 31, 36, 46]. Among developing countries, a small number of C. parvum infections have been reported in goats and sheep from Asia, including China [17, 47, 48], India [49], Jordan [50] and Turkey [51]. Our results, however, are in contrast to those from studies conducted in most African countries including Egypt [37], Tunisia [52] and Ethiopia [53], where C. parvum has thus far not been reported in small ruminants. Cryptosporidium parvum was also absent in sheep and goats in other studies in China [38, 41].

The $C$. parvum identified in the study belonged to the IIaA13G2R1 subtype. Although IIaA13G2R1 subtype is not a common C. parvum subtype and has not reported previously in sheep, it was detected in some calves in Belgium and Algeria [54, 55], ponies in the USA [56], calves and goat kids in Turkey [51], and humans in Malaysia [57], indicating that it is likely a zoonotic pathogen in a broad range of areas. Similarly, the C. ubiquitum in goats in the present study was subtyped as XIIa, a well-known subtype family in goats elsewhere, including Greece [18], China [17, 38] and Australia [45]. It is also commonly reported in sheep in many countries $[26,35,41]$. It is responsible for zoonotic C. ubiquitum infection in humans in industrialized countries, especially the UK [26].

In this study, C. parvum, C. xiaoi and C. ubiquitum infections occurred mostly in animals younger than three weeks. This agrees with observations in previous studies $[10,17,18,34,37-40,47]$. Currently, controversy exists on the clinical significance of C. ubiquitum and C. xiaoi [2]. In the present study, most $C$. xiaoi cases (11/12), the two C. ubiquitum and the three C. parvum cases all had diarrhea. Cryptosporidium infections in lambs and goat kids have been associated with the occurrence of diarrhea in some studies $[10,16,32,34,39,40]$. Case-control studies are needed to confirm the role of C. ubiquitum and C. xiaoi in the induction of diarrhea in infected animals.

\section{Conclusions}

Results of this study showed a relatively common occurrence of C. xiaoi in lambs and goat kids in association with the occurrence of diarrhea. The additional presence of zoonotic C. parvum and C. ubiquitum indicates that cryptosporidiosis in small ruminants may have further public health implications. More extensive molecular epidemiological studies are needed to substantiate these observations and to improve our understanding of the epidemiology and public health significance of cryptosporidiosis in small ruminants in Algeria.

\section{Acknowledgements}

We thank Laathamna Abdelkarim of the University Ziane Achor of Djelfa for statistical analysis. The findings and conclusions in this report are those of the authors and do not necessarily represent the views of the Centers for Disease Control and Prevention.

\section{Funding}

This work was supported in part by the National Natural Science Foundation of China (31425025)

\section{Availability of data and materials}

The data supporting the conclusions of this article are included within the article. Representative sequences generated in the study were submitted to GenBank under the accession numbers JX412917 and LC414387-LC414394.

\section{Authors' contributions}

$D B, A H, D K, Y F$ and $L X$ conceived the study. DB, AH, HA, SA, KA, HD, XC and $D R$ conducted the experiments. $D B, A H, S A$ and $L X$ analyzed the data; $D B$, $S A, A H$ and $L X$ prepared the report. All authors read and approved the final manuscript.

\section{Ethics approval}

The procedures used in this investigation comply fully with ethics regulations in Algeria. The study protocol was approved by ethics committee of École Nationale Supérieure Vétérinaire, Algiers, Algeria (PROJET CNEPRU/ CODE: F02620130033).

Consent for publication

Not applicable.

\section{Competing interests}

The authors declare that they have no competing interests.

\section{Publisher's Note}

Springer Nature remains neutral with regard to jurisdictional claims in published maps and institutional affiliations.

\section{Author details}

'École Nationale Supérieure Vétérinaire, Rue Issaad Abbes, El Alia, Alger, Algérie. ${ }^{2}$ Division of Foodborne, Waterborne and Environmental Diseases, Centers for Disease Control and Prevention, 1600 Clifton Road, Atlanta, GA 30329, USA. 'aboratoire exploration et valorisation des écosystèmes steppique, Université Ziane Achor, 17000 Djelfa, Algérie. ${ }^{4}$ Department of Biology, Addis Ababa University, Addis Ababa, Ethiopia. ${ }^{5}$ Department of Zoology, Faculty of Science, Kafr El Sheikh University, Kafr El Sheikh 33516, Egypt. 'UMR-BIPAR, ANSES-Ecole Nationale Vétérinaire d'Alfort,

Maisons-Alfort, Paris, France. ${ }^{7}$ Université Saad Dahleb Blida, Blida, Algérie. ${ }^{8}$ Beijing Tropical Medicine Research Institute, Beijing Friendship Hospital, Beijing 100050, China. ${ }^{9}$ Key Laboratory of Zoonosis of Ministry of Agriculture, College of Veterinary Medicine, South China Agricultural University, Guangzhou 510642, China.

Received: 9 August 2018 Accepted: 25 October 2018

Published online: 06 November 2018

References

1. Ryan U, Fayer R, Xiao L. Cryptosporidium species in humans and animals: current understanding and research needs. Parasitology. 2014;141:1667-85.

2. Xiao L. Molecular epidemiology of cryptosporidiosis: an update. Exp Parasitol. 2010:124:80-9.

3. Santin M. Clinical and subclinical infections with Cryptosporidium in animals. N Z Vet J. 2013;6:1-10

4. Quílez J, Torres E, Chalmers R, Hadfield S, Del Cacho E, Sánchez-Acedo C. Cryptosporidium genotypes and subtypes in lambs and goat kids in Spain. Appl Environ Microbiol. 2008;74:6026-31. 
5. Robertson L. Giardia and Cryptosporidium infections in sheep and goats: a review of the potential for transmission to humans via environmental contamination. Epidemiol Infect. 2009;137:913-21.

6. Kotkova M, Nemejc K, Sak B, Hanzal V, Kvetonova D, Hlaskova L, et al. Cryptosporidium ubiquitum, C. muris and Cryptosporidium deer genotype in wild cervids and caprines in the Czech Republic. Folia Parasitol (Praha). 2016;63:3.

7. Olson M, Ralston B, O'Handley R, Guselle N, Appelbee A. What is the clinical and zoonotic significance of cryptosporidiosis in domestic animals and wildlife. In: Thompson RC, Armson A, Ryan UM, editors. Cryptosporidium: From Molecules to Disease. Amsterdam: Elsevier B.V; 2003.

8. Noordeen F, Rajapakse R, Horadagoda N, Abdul-Careem M. Cryptosporidium, an important enteric pathogen in goats - a review. Small Rumin Res. 2012; 106:77-82.

9. Paraud C, Chartier C. Cryptosporidiosis in small ruminants. Small Rumin Res. 2012;103:93-7.

10. Díaz P, Quílez J, Prieto A, Navarro E, Pérez-Creo A, Fernández G, et al. Cryptosporidium species and subtype analysis in diarrhoeic preweaned lambs and goat kids from north-western Spain. Parasitol Res. 2015;114 4099-105.

11. Peng $X Q$, Tian $G R$, Ren GJ, Yu ZQ, Lok JB, Zhang $L X$, et al. Infection rate of Giardia duodenalis, Cryptosporidium spp. and Enterocytozoon bieneusi in cashmere, dairy and meat goats in China. Infect Genet Evol. 2016;41:26-31.

12. Romero-Salas D, Alvarado-Esquivel C, Cruz-Romero A, Aguilar-Domínguez M, Ibarra-Priego N, Merino-Charrez JO, et al. Prevalence of Cryptosporidium in small ruminants from Veracruz, Mexico. BMC Vet Res. 2016;12:14.

13. Shafieyan H, Alborzi A, Hamidinejat $H$, Tabandeh M, Hajikolaei M. Prevalence of Cryptosporidium spp. in ruminants of Lorestan province, Iran. J Parasit Dis. 2016:40:1165-9.

14. Kaupke A, Michalski M, Rzeżutka A. Diversity of Cryptosporidium species occurring in sheep and goat breeds reared in Poland. Parasitol Res. 2017; 116:871-9.

15. Giles M, Chalmers R, Pritchard G, Elwin K, Mueller-Doblies D, Clifton-Hadley F. Cryptosporidium hominis in a goat and a sheep in the UK. Vet Rec. 2009; 164:24-5.

16. Díaz P, Quílez J, Robinson G, Chalmers R, Díez-Baños P, Morrondo P. Identification of Cryptosporidium xiaoi in diarrhoeic goat kids (Capra hircus) in Spain. Vet Parasitol. 2010;172:132-4.

17. Mi R, Wang X, Huang Y, Zhou P, Liu Y, Chen Y, et al. Prevalence and molecular characterization of Cryptosporidium in goats across four provincial level areas in China. PLoS One. 2014;9:e111164.

18. Tzanidakis N, Sotiraki S, Claerebout E, Ehsan A, Voutzourakis N, Kostopoulou $D$, et al. Occurrence and molecular characterization of Giardia duodenalis and Cryptosporidium spp. in sheep and goats reared under dairy husbandry systems in Greece. Parasite. 2014;21:45.

19. Xiao L, Feng Y. Molecular epidemiologic tools for waterborne pathogens Cryptosporidium spp. and Giardia duodenalis. Food Waterborne Parasitol. 2017;8-9:14-32.

20. Baroudi D, Khelef D, Goucem R, Adjou K, Adamu H, Zhang H, Xiao L. Common occurrence of zoonotic pathogen Cryptosporidium meleagridis in broiler chickens and turkeys in Algeria. Vet Parasitol. 2013;196:334-40.

21. Laatamna AE, Wagnerová $P$, Sak $B$, Květoňová $D$, Xiao L, Rost $M$, et al. Microsporidia and Cryptosporidium in horses and donkeys in Algeria: detection of a novel Cryptosporidium hominis subtype family (Ik) in a horse. Vet Parasitol. 2015;208:135-42.

22. Baroudi D, Khelef D, Hakem A, Abdelaziz A, Chen X, Lysen C, et al. Molecular characterization of zoonotic pathogens Cryptosporidium spp., Giardia duodenalis and Enterocytozoon bieneusi in calves in Algeria. Vet Parasitol Reg Stud Rep. 2017;8:66-9.

23. Baroudi D, Zhang H, Amer S, Khelef D, Roellig DM, Wang Y, et al. Divergent Cryptosporidium parvum subtype and Enterocytozoon bieneusi genotypes in dromedary camels in Algeria. Parasitol Res. 2018;117:905-10.

24. Feng $Y$, Ortega $Y$, He G, Das $P, X u$ M, Zhang $X$, et al. Wide geographic distribution of Cryptosporidium bovis and the deer like genotype in bovines. Vet Parasitol. 2007;144:1-9.

25. Alves M, Xiao L, Sulaiman I, Lal A, Matos O, Antunes F. Subgenotype analysis of Cryptosporidium isolates from humans, cattle, and zoo ruminants in Portugal. J Clin Microbiol. 2003;41:2744-7.

26. Li N, Xiao L, Alderisio K, Elwin K, Cebelinski E, Chalmers R, et al. Subtyping Cryptosporidium ubiquitum, a zoonotic pathogen emerging in humans. Emerg Infect Dis. 2014;20:217-4.
27. Fayer R, Santin M. Cryptosporidium xiaoi n. sp. (Apicomplexa: Cryptosporidiidae) in sheep (Ovis aries). Vet Parasitol. 2009;146:192-200.

28. da Silva AJ, Caccio S, Williams C, Won KY, Nace EK, Whittier C, et al. Molecular and morphologic characterization of a Cryptosporidium genotype identified in lemurs. Vet Parasitol. 2003;111:297-307.

29. Causapé AC, Quílez J, Sánchez-Acedo C, del Cacho E, López-Bernad F. Prevalence and analysis of potential risk factors for Cryptosporidium parvum infection in lambs in Zaragoza (northeastern Spain). Vet Parasitol. 2002;104: 287-98.

30. Santín M, Trou J, Fayer R. Prevalence and molecular characterization of Cryptosporidium and Giardia species and genotypes in sheep in Maryland. Vet Parasitol. 2007;146:17-24.

31. Mueller-Doblies D, Giles M, Elwin K, Smith RP, Clifton-Hadley FA, Chalmers R. Distribution of Cryptosporidium species in sheep in the UK. Vet Parasitol. 2008;154:214-9.

32. Imre K, Luca C, Costache M, Sala C, Morar A, Morariu S, et al. Zoonotic Cryptosporidium parvum in Romanian newborn lambs (Ovis aries). Vet Parasitol. 2013;191:119-22.

33. Cacciò SM, Sannella AR, Mariano V, Valentini S, Berti F, Tosini F. Pozio E. A rare Cryptosporidium parvum genotype associated with infection of lambs and zoonotic transmission in Italy. Vet Parasitol. 2013;191:128-31.

34. Rieux A, Paraud C, Pors I, Chartier C. Molecular characterization of Cryptosporidium spp. in pre-weaned kids in a dairy goat farm in western France. Vet Parasitol. 2013;192:268-72.

35. Yang R, Jacobson C, Gardner G, Carmichael I, Campbell AJ, Ng-Hublin J, Ryan U. Longitudinal prevalence, oocyst shedding and molecular characterisation of Cryptosporidium species in sheep across four states in Australia. Vet Parasitol. 2014;200:50-8

36. Goma FY, Geurden T, Siwila J, Phiri I, Gabriel S, Claerebout E, Vercruysse J. The prevalence and molecular characterisation of Cryptosporidium spp. in small ruminants in Zambia. Small Rumin Res. 2007;72:77-80.

37. Mahfouz M, Mira N, Amer S. Prevalence and genotyping of Cryptosporidium spp. in farm animals in Egypt. J Vet Med Sci. 2014;76:1569-75.

38. Wang R, Li G, Cui B, Huang J, Cui Z, Zhang S, et al. Prevalence molecular characterization and zoonotic potential of Cryptosporidium spp. in goats in Henan and Chongqing, China. Exp Parasitol. 2014;142:11-6.

39. Zucatto A, Aquino M, Inácio S, Figueiredo R, Pierucci J, Perri S, et al. Molecular characterisation of Cryptosporidium spp. in lambs in the South Central region of the State of São Paulo. Arq Bras Med Vet Zootec. 2015;67: $441-6$.

40. Siddiki A, Mina S, Farzana Z, Ayesa B, Das R, Hossain M. Molecular characterization of Cryptosporidium xiaoi in goat kids in Bangladesh by nested PCR amplification of 18S rRNA gene. Asian Pac J Trop Biomed. 2015; 5:202-7.

41. Li P, Cai J, Cai M, Wu W, Li C, Lei M, et al. Distribution of Cryptosporidium species in Tibetan sheep and yaks in Qinghai, China. Vet Parasitol. 2016;215: 58-62.

42. Parsons MB, Travis D, Lonsdorf EV, Lipende I, Roellig DM, Collins A, et al. Epidemiology and molecular characterization of Cryptosporidium spp. in humans, wild primates, and domesticated animals in the Greater Gombe Ecosystem, Tanzania. PLoS Negl Trop Dis. 2015;9:e0003529.

43. Wang Y, Feng Y, Cui B, Jian F, Ning C, Wang R, Zhang L, Xiao L. Cervine genotype is the major Cryptosporidium genotype in sheep in China. Parasitol Res. 2010;106:341-7.

44. Robertson L, Björkman C, Axén C, Fayer R. Cryptosporidiosis in farmed animals. In: Cacciò SM, Widmer G, editors. Cryptosporidium: Parasite and Disease. Vienna: Springer; 2014. p. 149-236.

45. Al-Habsi K, Yang R, Williams A, Miller D, Ryan U, Jacobson C. Zoonotic Cryptosporidium and Giardia shedding by captured rangeland goats. Vet Parasitol Reg Stud Rep. 2017;7:32-5.

46. Drumo R, Widmer G, Morrison L, Tait A, Grelloni V, D'Avino N, et al. Evidence of host-associated populations of Cryptosporidium parvum in Italy. Appl Environ Microbiol. 2012;78:3523-9.

47. Ye J, Xiao L, Wang Y, Wang L, Amer S, Roellig DM, et al. Periparturient transmission of Cryptosporidium xiaoi from ewes to lambs. Vet Parasitol. 2013;197:627-33.

48. Mi R, Wang X, Huang Y, Mu G, Zhang Y, Jia H, et al. Sheep as a potentia source of cryptosporidiosis in China. Appl Environ Microbiol. 2018;84:17.

49. Maurya PS, Rakesh RL, Pradeep B, Kumar S, Kundu K, Garg R, et al. Prevalence and risk factors associated with Cryptosporidium spp. infection in young domestic livestock in India. Trop Anim Health Prod. 2013;45:941-6. 
50. Hijjawi N, Mukbel R, Yang R, Ryan U. Genetic characterization of Cryptosporidium in animal and human isolates from Jordan. Vet Parasitol. 2016;228:116-20

51. Taylan-Ozkan A, Yasa-Duru S, Usluca S, Lysen C, Ye J, Roellig DM, et al. Cryptosporidium species and Cryptosporidium parvum subtypes in dairy calves and goat kids reared under traditional farming systems in Turkey. Exp Parasitol. 2016;170:16-20

52. Soltane R, Guyot K, Dei-Cas E, Ayadi A. Prevalence of Cryptosporidium spp. (Eucoccidiorida: Cryptosporiidae) in seven species of farm animals in Tunisia. Parasite. 2007;14:335-8.

53. Wegayehu T, Karim MR, Li J, Adamu H, Erko B, Zhang L, Tilahun G. Prevalence and genetic characterization of Cryptosporidium species and Giardia duodenalis in lambs in Oromia Special Zone, Central Ethiopia. BMC Vet Res. 2017;13:22.

54. Geurden T, Berkvens D, Martens C, Casaert S, Vercruysse J, Claerebout E. Molecular epidemiology with subtype analysis of Cryptosporidium in calves in Belgium. Parasitology. 2007;134:1981-7.

55. Benhouda D, Hakem A, Sannella AR, Benhouda A, Cacciò SM. First molecular investigation of Cryptosporidium spp. in young calves in Algeria. Parasite. 2017;24:15.

56. Wagnerová P, Sak B, McEvoy J, Rost M, Sherwood D, Holcomb K, Kváč M. Cryptosporidium parvum and Enterocytozoon bieneusi in American Mustangs and Chincoteague ponies. Exp Parasitol. 2016;162:24-7.

57. Iqbal A, Lim YA, Surin J, Sim BL. High diversity of Cryptosporidium subgenotypes identified in Malaysian HIV/AIDS individuals targeting gp60 gene. PLoS One. 2012;7:e31139.

Ready to submit your research? Choose BMC and benefit from:

- fast, convenient online submission

- thorough peer review by experienced researchers in your field

- rapid publication on acceptance

- support for research data, including large and complex data types

- gold Open Access which fosters wider collaboration and increased citations

- maximum visibility for your research: over $100 \mathrm{M}$ website views per year

At $\mathrm{BMC}$, research is always in progress.

Learn more biomedcentral.com/submissions 